\title{
The Implementation of Inclusive Education in Indonesia for Children with Special Needs: Expectation and Reality
}

\author{
Mohammad Efendi \\ Universitas Negeri Malang, Indonesia \\ Email: efendi.plb@gmail.com
}

\begin{abstract}
Government efforts to legitimize the implementation of inclusive education for children with special needs in regular schools ranging from primary education to secondary education, the more opportunities to expand opportunities for children with special needs in order to obtain quality education services. However, good policy is not balanced with the readiness of the recommended schools to provide adequate learning facilities and resource support. As a result, there is an indication that the special needs of children's education in inclusive schools have not received appropriate educational services based on their needs.
\end{abstract}

Keyword: inclusive education, children with special needs

\section{INTRODUCTION}

The development of science and technology impacting innovative works in various fields of life. It did not correlate with the decline of children with special needs population. Otherwise, the advancement of civilization expected to suppress the incidences of births with physical and/or mental barriers may not be able to withstand the "boom" incidents of children with special needs, especially in cases of autism.

The presence of special needs children around us automatically requires special education services to suit their needs. The urgency of children with special needs requires special education services so that they can develop their maximum potential, “... Who deviates from the average or normal child in mental, physical, or social characteristics educational services in order to develop to his maximum capacity" (Efendi, 2010). A similar opinion is expressed by Schulz et al. (1995), which is "...those who require special education and related services if they are to realize their full human potential" (Hallahan \& Kaufman, 1991).

Developing the potential and capacity of children with special needs to the maximum is not easy. For that, adequate supporting resources are needed, including specific learning facilities, special learning professional and non-academic treatment, students' friendly environment, operational costs, and others. Cumulatively, if calculated the need for the cost of education of children with special needs is relatively expensive, while the output resulting from the process in quantity is not significant and unbalanced by the amount of cost spent. Based on these assumptions, the policymakers who do not have a good commitment rarely give priority scale to the development of children with special needs potential, because the productivity contribution from the students with special needs is not as good as normal child productivity.

Whatever the circumstances, the presence of children with special needs in the community needs to get the same rights to obtain quality education like any other normal child. Because education is the only effort needed by children with special needs to be able to help themselves and adapt to the environment (Efendi, 2017). Therefore, the more children with special needs who receive accurate educational services, it will be more and more populations of children with special needs who are skilled in adapting and being able to help himself. In turn, this condition directly affects the reduction of maintenance costs for them throughout life. Another important effect, namely the increasing number of children with special needs who are educated and skilled, indirectly also increase self-esteem and dignity as a nation (Efendi, 2006).

The existence of children with special needs in small groups or large groups community still has a negative stigma. Just by looking at certain temporary physical and behavioral conditions, they spontaneously assign certain labels to the individuals identified in the category. This exact spontaneous perception is very dangerous, because if we misinterpret the condition and characteristic of a person perceived to have a disability we have committed "killing" of the potential that should be grown.

According to academic norms, to include those identified in certain abnormal categories requires complete and accurate information, especially from families, professionals/experts, or the children themselves because the physical and mental indicators 
identified as "visible abnormalities" are instantly a verdict for labeling someone in a special needs category. Yet to arrive at these conclusions, accurate information is still needed that is explored through the assessment. Sometimes, clinically or empirically someone identified appears to be experiencing certain obstacles, but the disorder is not significant and does not require special education services, so he is not included in the category of children with special needs.

Related to the educational services of children with special needs in Indonesia, in its development is available in two education models, namely segregation, and integration. Segregation education in Indonesia is known as Sekolah Luar Biasa with units of its units, among others: TKLB (Preschool for special needs child), SDLB (Primary school for special needs child), SMPLB (secondary school for special needs child), and SMALB (senior high school for special needs child). While the form of integrated education, among others: Integrated Education (mixed with normal children and use the general school curriculum) and Inclusive Education (mixing with normal children using the curriculum according to the needs of learners with special needs). The implementation of this integration and inclusive model alone provides access to a wider range of services to students with special needs (Slavin, 2011).

The provisions governing that children with special needs are entitled to receive education together with normal children, other than through the ratification of consensus in international meetings, among others: The Salamanca Statement on Inclusive Education in 1994, The Dakar Commitment on Education for All 2000, also through national regulation , Among others: 1945 Constitution (amendment) article 31 paragraph 1 and 2; Law No. 23/2002 on Child Protection, Law No. 20/2003 on National Education System. While the regulations under it that support the right to education services for children with special needs, among others: Government Regulation No. 19/2005 on National Education Standards explaining that special education units consist of SDLB (primary schools), SMPLB (secondary schools) and SMALB (senior secondary schools); Regulation of the Minister of National Education No. 70/2009 on inclusive education for learners who have abnormalities and have special intelligence and / or talent potential; Notification letter from the Director General of Primary and Secondary Education, Ministry of National Education no. 380/C.C6/MN/2003 dated January 20, 2003, on the Implementation of inclusive education in each district/ municipality of at least 4 (four) schools comprising of primary, junior high schools, senior secondary and vocational schools (Efendi, 2014).

Many regulations support the implementation of inclusive education models in Indonesia, indicating that the Indonesian government's attention to improving the quality of human resources with special needs require being followed up consistently by policymakers for its implementation process. In this regard, there are some questions that Inclusive education providers need to ponder, such as Is the integration of children with special needs into regular classes in improving their performance? Are regular student responses positive enough? Is the learning model applied in the inclusive classroom Effective enough?, Is the learning media used is in accordance with the class character? Is the design of learning that is prepared in accordance with the target group?, Do regular teachers have the readiness to face children with special needs? Is the competence of teachers is adequate for inclusion class?, Do supporting facilities need to be improved by schools? and so on.

\section{METHOD}

The purpose of this study is to describe qualitatively the empirical facts between the expectations and reality of the implementation of inclusive education in Indonesia for children with special needs. Therefore, this research uses literature research design and utilize primary sources and secondary sources to obtain research data. In other words, this library research limits its activities on collecting data through library collection materials (manuals and internet), without the need for field research. In its implementation, the series of research activities of this library relates to the method of collecting data library, reading and recording and processing materials research results.

There are several reasons for the use of this literature research, among others: (1) the issues that become the topic of this research in preliminary research is a new phenomenon that is developing and gets quick response from the community, (2) availability of documentation on implementation of inclusive education for children with special needs from policy makers from various levels to answer research problem, (3) Empirical information or data that has been collected by others, in the form of reports of research results, official reports, books stored in the library can be used to answer the problem of this research.

\section{FINDINGS AND DISCUSSION}

\section{Findings}

Based on the fact that the growth of special needs children from year to year continues to increase significantly, impact on the provision of education services. Among those categorized as children with special needs, some are served together with other students of a similar or common type in regular 
schools. Even among them may also need a specific service, because identifiable experience differences in characteristics are very significant. In this regard, educational services to students with special needs are: (1) designed in a regular education format, (2) specially designed for special education because it meets the criteria of a disabled or disability law (Choate, 2004). In the first case, failures in learning in a group of students with attention deficits, failures of reading (dyslexia), are unable to follow rhythms or general learning models, sociocultural or economic pressures, and so on. Whereas in the second case, formal failure according to their diagnosis is categorized as persons with disabilities, so special educators are required.

Distribution of children with special needs, in fact, does not focus on a particular area, an obstacle that can make it difficult for policy makers to accommodate their educational services. In the United States, it is estimated that only about $0.5 \%$ of children with disabilities attend special schools, others are in regular schools (Ashman \& Elkins, 1998), and the estimated population of learners in special schools is less than $3 \%$ of children with disabilities (Authority, 1985). This means that $97 \%$ of children with other special needs receive educational services that are not reachable through special schools. The prevalence of children in Indonesia according to the Badan Pusat Statistik (BPS) according to the National Socioeconomic Survey in 2009 , the total number of persons with disabilities in Indonesia is 2,126,998 persons, with details: $338,796.85$ (15.93\%) blind, 223,737.78 (10.52\%) deaf, 151,427.09 (7.12\%) speech disorder, 73,586.76 (3.46\%) deaf and speech disorder, 717,798.94 (33.75) obstacles of physical function and motion , 290,944.19 (13.68\%) intellectual disability, 149,512.99 (7,03\%) multiple handicapped, and 181,202.08 (8,52\%) psychiatric disorders (Kemdikbud, 2013).

Based on the records compiled by USAID, in 2011 the composition of schools that serve the education of children with special needs in Indonesia include 1858 special schools, 1654 regular primary schools, and 320 regular secondary schools. More than 73.100 people are served in special school, more than 29.700 people are served in inclusive schools (primary \& junior high school). The World Health Organization (2008) report is known that $20 \%$ of children with special needs age 6-11 years and $19 \%$ of children with special needs age 12-17 have a chance to learn (Baine, 2013). The low participation of learners with special needs to get an education in accordance with their needs need to have the right solution.

Referring to data from the "International Consultative Forum on Education for All" (2000) in this world there are 113 million children of primary school age who are not in school. $90 \%$ of these are in low- to middle-income countries, and more than
80 million such children live in African countries. Even if some are able to school, some of them drop out (drop out of school) when the education process has not been completed. The right solution to expand access to education for children with special needs is the placement of children with special needs level light, moderate, and full weight in the general class (Staub \& Peck, 1995). An education service system that requires all children with disabilities or special needs children to be served in nearby schools in regular classes with their peers to optimize their potential through inclusive education (O'Neil, 1995). This effort is based on the reason that in the community the presence of normal children and children with special needs is not separated as a community. Recognising the essence, the model of inclusive education as an option to expand access to education services for children with special needs, in recent years many provincial and district governments in Indonesia have legitimated the implementation of inclusive education programs in their respective regions.

The urgency of inclusive education programs in Indonesia is stronger when provincial, district or municipal governments initiate inclusive education movements for children with special needs, reinforced by governorship rules, regent regulations and mayoral regulations. Examples of provincial level areas that legitimize inclusive education are Governor Regulation of DKI No. 116/2007, Governor Regulation of East Java No. 6/2011, Governor Regulation of Aceh No. 92/2012, Governor Regulation of DIY No. 21/2013 and other provinces follow suit. Likewise, at the Regency or municipal level, among others are: Regency Regulation of Banyuwangi District No. 68/2012, Regency Regulation of Tuban District No. 51/2012, Regency Regulation of Gresik District No. 42/2013, Regency Regulation of Jombang District No. 39/2014, Regency Regulation of Bojonegoro District No. 39/2014, City Government Regulation of Malang No. 425/0555/35.73.307/2009, and other regents/mayors followed suit. The high level of government regulation support, does it directly affect the implementation of the inclusive education model in Indonesia? Here are some empirical facts that have been elaborated from the results of studies at several inclusive education providers in several cities in Indonesia.

\section{Discussion}

The results of the Tarmansyah (2009) study that took the case in West Sumatra showed that the constraints of inclusive implementation lie in the difficulties of bureaucracy, curriculum management, teacher competence, learning materials and cooperation with parents and communities. These conditions generally stem from the lack of understanding of the 
community, the limited ability of school personnel who have the competence to modify, limited resources in schools, and the importance of training to school principals, teachers, and school personnel before implementation (Yusuf \& Yeager, 2011).

In many instances, particularly based on geographical considerations of the territory of Indonesia, that the implementation of inclusive education programs as a solution of access expansion for learners with special needs is the right choice to increase the participation rate of children with special needs in the context of compulsory education (Efendi, 2010). Nevertheless, Top-Down implementation recommendations still seem to need to be evaluated for their effectiveness. At least preliminary results indicate that the readiness of the instruments and the absolute support resources are taken into account before program implementation, including regulatory regulation. The results of the study on the readiness of elementary schools recommended by the city government of Malang to provide inclusive education concluded: (1) some identified research schools are incapable of continuing the inclusive program due to the lack of resources; (2) the performance of special education teachers secondary in schools has learning experience (Only through seminars, workshops, short courses) and not special education graduates, (3) school readiness in providing the necessary facilities and infrastructure to optimize the potential development of students with special needs has not been met. (4) environmental support has not fully appreciated the inclusive education program for students with special needs (Efendi, 2011).

To achieve good results in the implementation of inclusive education, it is worth considering the following principles: (1) educational goals directed to all children (knowledge, skills and values); (2) curriculum flexibility that allows responding to diversification and providing opportunities to achieve (3) assessment based on individual progress, (4) taught material knowledge and skills must be relevant to the child (Unesco, 1994)

The basic principle of inclusive education is to the extent possible that all children should learn together regardless of the difficulties or differences that exist in themselves (Slavin, 2011). "Inclusive education means that ... schools should accommodate all children regardless of their physical, intellectual, social, emotional, linguistic or other conditions. This should include disabled and gifted children, street and working children, children from remote or nomadic populations, children from linguistic, ethnic or cultural minorities and children from other disadvantaged or marginalized areas or groups". (The Salamanca Statement and Framework for Action on Special Needs Education).

At the national level, the policy on the implementation of inclusive education in Indonesia is supported by the Notification Letter of the Directorate General of Primary and Secondary Education No. 380/C.C6/MN/2003 on the implementation of inclusive education in each regency/municipal at least 4 (four) schools, consisting of Elementary Schools, Junior High Schools, Senior Secondary Schools, and Vocational Schools. Recommendations of Bukittinggi (2005) reinforces that inclusive and child-friendly education with special needs should be viewed as an approach and a way to ensure that all children receive the quality education and care in their community of residence. Related to it, the Government of Indonesia and the House of Representatives of the Republic of Indonesia have ratified the Convention on the Rights of persons with disabilities on 18 October 2011 (Baine, 2013).

Managerial implications to be anticipated when schools are set up to be inclusive institutions: maintaining warm classroom communication and respecting diversity, implementing curriculum heterogeneity, teacher preparation of interactive teaching, consultation and inter-team collaboration, parent/family involvement in program planning (Efendi, 2014). The study of achievement motivation in special education teachers teaching in inclusive schools is only a small percentage of teachers who have high achievement motivation in the category. Some indicators that contribute to achievement motivation on the performance of special education teachers in inclusive schools include: age, employment, income or salary, employment status and suitability of preteaching educational background of special education teachers contribute significantly to achievement motivation (Efendi, 2015).

In addition to formal legality, the implementation of inclusive education programs for children with special needs in regular schools is community cohesiveness to receive and responsive to the individual needs of students with special needs. Therefore, the learning profile in the inclusion school should reflect: (1) The application of a multi-level and multimodality curriculum, in which case the master has the responsibility of creating a classroom atmosphere that accommodates all children in full by emphasizing the atmosphere and social behavior that respects differences regarding capabilities, Physical, socio-economic, ethnic, religious, and so forth; (2) Application of learning model which refers to cooperative learning approach which involves inter-student cooperation, mutual teaching and learning, and actively participate and take responsibility for their own education and education of their friends. All children are in one class not to compete but to learn and teach with each other; (3) Cooperation between teachers and other professions (counselors, psychologists, doctors/paramedics, speech therapists, etc.) to collaborate and consult various ways 
of measuring and evaluating children's knowledge and skills; (4) Involvement of Individual Education Program (IEP) and home study assistance as a form of active participation of parents in the education of their children (Sunardi, 2002).

As it is known that the implementation of the inclusive education model varies widely, from the most extreme of fully integrated children in regular schools to the placement of special classes in regular schools. Most of the regular schools that are home base inclusive programs, initially all the components of the school deliberately designed to provide educational services for normal learners, so for that curriculum, educators, infrastructure facilities are not prepared for learners with special needs. Therefore, when implementing inclusive education, there needs to be a gradual adjustment or procurement (Kemdikbud, 2013).

In order to establish an inclusive education model (full, partial or special class) at regular schools, there are several indicators that can be taken into consideration: (1) the number of children with disabilities to be served, (2) the type of abnormality of each child, (3) gradation of abnormality children with special needs, (4) availability and readiness of education personnel, and (5) available facilities. Through the mapping of these 5 indicators, it is recommended the development of an accurate pattern of inclusive education modeling based on the needs and characteristics of learners.

Vaughn et al. (2000) recommends placement of children with special needs in inclusion schools can be done with various models, as follows: (1) children with learning disabilities with normal children throughout the day in regular classes using the same curriculum (full inclusion), (2) children with disabilities learn with normal children in regular classes in special groups (regular classes with clusters), (3) children with learning disabilities with normal children in regular classes but in certain times drawn from regular classes to the source room to study with special mentors (regular classes with pull outs), (4) disabled children learn with normal children in regular classes in special groups, and in certain times drawn from regular classes to the source room to study with special tutors (regular classes with clusters and pull Out), (5) children with learning disabilities in special classes in regular schools, but in certain areas can learn together normal in regular classes (special classes with different integration), and (6) children with disabilities in special classroom learning at regular schools (full special classes).

Based on the description it can be concluded that inclusive education does not require all disabled children to be in regular classes at all times with all subjects (full inclusion), as some children with disabilities may be in a special class or therapy room due to a severe gradation of the disorder. Even for children with disabilities that are gradations of severe abnormalities, it may be more time to be in a special classroom at a regular school (inclusion location). Then, for the graduation of the disorder is very heavy, and not possible in regular schools, can be channeled to special schools (SLB) or special place (hospital). Thus, the model of inclusive education between schools with one another does not necessarily be the same, so different time frames in the same school the model of inclusive education may vary, depending on the actual conditions occurring at the time.

Resulting of monitoring conducted by the Directorate of Special Education and Special Services, there are several obstacles identified in the implementation of inclusive education programs, such as professional organizations have not played an active role, lack of school understanding of inclusive education, teachers and policymakers in the regions are still varied and limited, human resources in inclusive schools are mostly difficulties in curriculum modification and academic assessments, there is still controversy over the public opinion about appropriate education for children with special needs, limited facilities and infrastructure (Wardi, 2013).

Regardless of the inclusive education model developed by regular or normal schools, it is certain that the implementation of inclusive education provides individual consequences for curriculum and teaching materials for students, educators, and other education, the provision of learning support facilities and infrastructure, school management, financing allocation, and the creation of an environment Schools, communities, and families that are conducive. Because, when in a class there are changes in student input, that is not only to accommodate normal children but also children with special needs, it requires adjustment (modification) curriculum and teaching materials, teacher participation, facilities, funds, management (class management) Environment, and teaching and learning activities. "... The curriculum can facilitate the development of more inclusive settings when it leaves the room for the center of learning or the individual teacher to make the adaptations so that it makes better sense in the local context and for the individual learner".

\section{CONCLUSION}

The growth of the population of special needs children every year there is a tendency to increase, while available special educational institutions are limited. Implementing an inclusive education model can expand the access of children with special needs for education services. In its implementation, the model of inclusive education has been supported by stakeholders, but the reality of its implementation is still constrained, especially limited resources and the school's environmental responses have not been fully 
responsive. The special needs of children's education in inclusive schools have not received appropriate educational services based on their needs.

It is worth things in implementation inclusive education: educational goals directed to all children (knowledge, skills, and values); the curriculum flexibility that allows responding to diversification and providing opportunities to achieve; the assessment based on individual progress; and the taught material knowledge and skills must be relevant to the child.

\section{REFERENCES}

Ashman, A., \& Elkin, J. (1998). Educating with Special Needs. Australian: Prentice Hall Australia Ltd.

Authority, I. L. E., \& Fish, J. (1985). Educational Opportunities for All?: Report of the Committee Reviewing Provision to Meet Special Educational Needs, Chaired by John Fish, Formerly HMI and Staff Inspector for Special Education. ILEA.

Baine, D. (2013). Anak Penyandang Disabilitas Di Negara Berkembang (terjemahan) Edmonton: Alberta University

Choate, J. S. (2004). Pengajaran Inklusif Yang Sukses (translate). Boston: The Allyn \& Bacon

Efendi, M. (2006). Pengantar Psikopedagogik Anak Berkelainan. Jakarta: Bumi Aksara.

Efendi, M. (2010). Implementasi Pendidikan Inklusif sebagai Alternatif Pendidikan Anak Berkebutuhan Khusus. Prosiding Seminar nasional Pendidikan Luar Biasa.

Efendi, M. (2011). Studi Evaluatif Kesiapan SD di kota Malang Untuk Menyelenggarakan pendidikan inklusif bagi Anak Berkebutuhan Khusus. Malang: Lembaga Penelitian Universitas Negeri Malang.

Efendi, M. (2014). Perspektif Pendidikan Inklusif. Malang: Fakultas Ilmu Pendidikan Universitas Negeri Malang.

Efendi, M. (2015) Contribution of External and Internal Factors Toward Achievement Motivation of The Special Education Teachers Performance in Inclusive Education. Prosiding Seminar Interenasional Special Education for South Asia Region-5 Surabaya.
Efendi, M. (2017). Laporan Penelitian Kebijakan Studi Evaluasi Implementasi Kurikulum Pendidikan Khusus 2013 di Sekolah Luar Biasa. Kerjsama Direktorat Pembinaan PLPK Dikdas Kemendikbd. Tidak diterbitkan.

Hallahan, D. P., \& Kauffman, J. M. (1991). Exceptional children: Introduction to Special Education. $5^{\text {th }}$ edition. Mexico: Prentice Hall Inc.

Kemdikbud. (2013). Pedoman Penyelenggaraan Program Dikjas Adaptif Bagi PDBK Di Sekolah Inklusif. Jakarta: Direktorat Pembinaan PKLK Dikdas Kemdikbud.

O’Neil, J. (1995). Can Inclusion Work? A Conversation with Jim Kauffman and Mara Sapon-Shevin. Educational Leadership, 52(4), 7-11.

Schulz, J. B., \& Carpenter, C. D. (1995). Mainstreaming exceptional students: A guide for classroom teachers. Allyn and Bacon.

Slavin, R. E. (2011). Psikologi pendidikan teori dan praktik. Jakarta: Indeks.

Staub, D., \& Peck, C. A. (1995). What Are the Outcomes for Nondisabled Students?. Educational leadership, 52(4), 36-40.

Sunardi. (2002). Kecenderungan dalam Pendidikan Luar Biasa. Jakarta: Depdikbud

Tarmansyah (2009). Pelaksanaan pendidikan inklusif di SD Alai Padang Utara. Pedagogi, 9(1).

Unesco. (1994). The Salamanca Statement and Framework for action on special needs education: adopted by the World Conference on Special Needs Education; Access and Quality. Salamanca, Spain, 7-10 June 1994. Unesco.

Vaughn, S., Bos, C., \& Schumm, J. (2000). Teaching Exceptional, Diverse, and at Risk Students in the General Educational Classroom. Boston: Allyn Bacon.

Wardi, H. (2013). Strategi umum pembudayaan pendidikan inklusif di Indonesia. Jakarta: Dir. Pembinaan PKLK Kemdikbud

Yusuf, M., \& Yeager, J. L. (2011). The implementation of inclusive education for students with special needs in Indonesia. Excellence in Higher Education, 2(1), 1-10. 